\title{
THE SIgNifICANCE OF TABAYYUN PRACTICE AS CONFLICT RESOLUTION IN INDONESIAN SOCIETY
}

\author{
David Eko Setiawan ${ }^{1 *}$ \\ ${ }^{1}$ Tawangmangu Theological College, Semarang, Central Java, Indonesia, e-mail: davidekosetiawan14217@gmail.com \\ *Corresponding Author

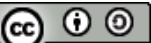 \\ C2021 by the authors. Submitted for possible open access publication under the terms and conditions of the Creative Commons \\ Attribution-ShareAlike 4.0 International License-(CC-BY-SA) (https://creativecommons.org/licenses/by-sa/4.0/) \\ doi DOI : http://dx.doi.org/10.30983/islam realitas. $77 i 2.4654$.
}

Submission: 12 October $2021 \quad$ Revised: 14 December $2021 \quad$ Published: 31 December 2021

\begin{abstract}
This article seeks to explain the significance of the practice of tabayyun as conflict resolution in Indonesian society. Indonesia is a multicultural country with considerable potential for conflict. To prevent that, it is necessary for local communities to be open to each other and try to find clarity on any problem arising so as not to cause prolonged conflict. In Islamic theology, this practice is called tabbaym. The research problem in this study is the extent to which the practice of tabayyun can contribute to conflict resolution in Indonesian society. This research uses a qualitative approach using library methods and is also supported by data from interviews with Muslim figures who have practiced tabayyun in resolving conflicts in society. The results of this study show that tabayynn practice has a significant role in solving social conflicts in Indonesian society, because it can improve the quality of information being conveyed and received, clarify the root causes in a conflict, prevent disasters due to unknown roots of problems in conflict, and foster social ethics based on religious values in Islamic theology.
\end{abstract}

Keywords: Significance, Tabayyun, Conflict resolution

\begin{abstract}
Abstrak
Artikel ini berupaya menjelaskan pentingnya praktik. Tabayyun sebagai penyelesaian konflik di masyarakat Indonesia. Masalah penelitian dalam penelitian ini adalah sejauh mana signifikansi praktik. Tabayyun dapat menjadi penyelesaian konflik di masyarakat Indonesia?. Indonesia adalab negara multikultural dengan potensi konflik yang cukup besar. Untuk. mencegah hal itu, perlu diwaspadai di masyarakat untuk saling terbuka dan berusaba mencari kejelasan sebuah permasalahan/informasi agar tidak menimbulkan konflik yang berkepanjangan. Dalam Teologi Islam, praktik ini disebut Tabbayun. Penelitian ini menggunakan pendekatan kualitatif dengan menggunakan metode kepustakaan dan juga didukung dengan data hasil wawancara dengan tokoh-tokoh muslim yang telah mengamalkan tabayyun dalam menyelesaikan konflik di masyarakat. Hasil penelitian ini menunjukkan bahwa praktik Tabayyun memiliki arti yang sangat besar dalam penyelesaian konflik. sosial di masyarakat Indonesia karena dapat meningkatkan kualitas informasi yang disampaikan dan diterima, memperjelas akar permasalahan dalam sebuah konflik, mencegah bencana karena ketidakjelasan akar permasalahan dalam konflik, dan menumbubkan etika sosial berdasarkan nilai-nilai agama dalam teologi Islam.
\end{abstract}

Kata Kunci: Signifikansi, Tabayyun, Penyelesaian konflik

\section{Background}

Indonesia is known as a multicultural country rich in ethnic diversity, customs, religions, and beliefs ${ }^{1}$. According to Suprihatin and Nasution, Indonesia has two types of diversity, namely vertical and horizontal ${ }^{2}$. Vertical diversity concerns social, economic, political, and educational differences, while horizontal diversity relates to differences in social unity covering regional languages, indigenous clothing, culinary traditions, and other symbols attached to each
1 Sagaf S Pettalongi, 'Islam dan Pendidikan Humanis dalam Resolusi Konflik Sosial', Cakrawala Pendidikan, $\quad 0.2 \quad$ (2013), $\quad 172-82$ <https://doi.org/10.21831/cp.v0i2.1474>.
2 Atin Supriatin and Aida Rahmi Nasution, 'Implementasi Pendidikan Multikultural dalam Praktik Pendidikan di Indonesia', Elementary: Jurnal Ilmiah Pendidikan Dasar, $3.1 \quad$ (2017), 1 <https://doi.org/10.32332/elementary.v3i1.785>. 
ethnicity $^{3}$. Diversity can also be a capital for the development of the nation, but it can also be a trigger for social conflict in society. With these differences, there can sometimes be potential conflicts between individuals and groups. Pattalongi points out that since the Reformation era, many social conflicts in Indonesia tend to be destructive due to ethnic, religious, racial, and class conflicts ${ }^{4}$.

However, is it true that social conflicts are always caused by ethnic, religious, racial, and class motives? Panggabean in his research shows that social conflicts of religious background in Indonesia are caused by rivalry in contesting economic, political, and public positions in government ${ }^{5}$. This is in line with Jati's opinion that religion is often only used as a mask in various social conflicts in Indonesia, when in fact the conflict is derived from the interests of certain individuals and groups ${ }^{6}$. Religious diversity does not stand at the core of the conflict ${ }^{7}$. Lindawaty in the conclusion of his research on the root of the problem and solutions to the conflict in Ambon shows that the roots of social conflicts that occurred in Ambon (which resurfaced in 2011) are the result of economic, political, and socio-cultural injustice in the community, while religious motives are just triggers of the conflict ${ }^{8}$. Therefore, there needs to clarify the root of the problem and the motives behind social conflict so that the conflicting parties can resolve it appropriately and correctly.

In Islamic theology, clarifying the root cause of potential conflict is emphasized. This

${ }^{3}$ Supriatin and Nasution.

${ }^{4}$ Pettalongi.

5 S. Rizal Panggabean, Pola-Pola Konflik Keagamaan di Indonesia (1990-2008) (Jakarta: Asia Foundation, 2009), p. 7.

6 Wasisto Raharjo Jati, 'Kearifan Lokal Sebagai Resolusi Konflik Keagamaan', Walisongo: Jurnal Penelitian Sosial Keagamaan, 21.November (2013), 393-416.

${ }^{7}$ Jati.

8 Debora Sanur Lindawaty, 'Konflik Ambon: Kajian terhadap Beberapa Akar Permasalahan dan Solusinya', Politica, 2.2 (2011), 271-97.

9 Brian Rafsanjani, 'Sikap Tabayyun dalam AlQur'an Menurut Mufassir dan Kontekstualisasi pada practice is called tabbayun. Tabbayun means to examine the truth carefully about news or information, so that there is no misunderstanding and conflict in a society 9 . Azzuhri argues that, based on linguistic analysis and some verses correlated with the word, tabbayun means to investigate or prove the validity of a claim in order to properly clarify its meaning ${ }^{10}$. This practice is important when there is a dispute in society. Tabayyun's absence will not only lead to wrong decisions but can also lead to major conflicts in society and can even trigger disintegration ${ }^{11}$. In interviews with several Muslim figures, researchers found that social conflicts in society are sometimes triggered by problems that are not properly clarified. K.H. Khuzaini, Chairman of the Religious Harmony Forum of Karanganya Regency, Central Java said that hoax news can be one of the sources of division among religious people, because in it there is an element of untruth that has not been clarified ${ }^{12}$. K.H. Hafidi, he caretaker of Pondok Pesantren Darul Amal, Jatioso, Karanganyar, explained that divisions among the community are sometimes caused by unclear problems that give rise to slander, so according to him there is a need for tabayyun in order to obtain the truth ${ }^{13}$.

What then is the correlation between tabayyun and the resolution of social conflicts in society? Several studies have been attempted to elaborate on this, such as Atabiak's research which concluded that tabayyun can be one of the gender-based methods of conflict resolution for Indonesian women in the perspective of the

Problematika Pemberitaan Media Sosial' (UIN Sunan Ampel, 2018), p. 20.

10 Anggi Azzuhri, "Tabayyun As a Crucial Aspect in the Quranic Concept of Ummah Analysis of "Tabayyun" in Sura Al-Hujuraat (49:6)', Hunafa: Jurnal Studia Islamika, 17.2 (2020), 145-65 (pp. 153-57) <https://doi.org/10.24239/jsi.v17i2.603.27-46>.

11 Azzuhri.

12 Khuzaini, (Source of social conflict) Interview, \{Tuesday, 26 Oktober 2021\}

13 Hafidi, (Source of social conflict) Interview, \{Tuesday, 26 Oktober 2021\} 
Qur'an ${ }^{14}$. Another researcher is Hasana, who concluded that one of the conflict management activities that can be done by the head of Islamic education institutions in resolving conflicts in his institution is to implement tabayyun ${ }^{15}$. Furthermore, Indraswari and Prasetyo found that tabayyun can be an effective method for managing business conflicts from an Islamic perspective ${ }^{16}$. In addition, in interviews with Muslim figures found that through tabbayun conflicts that occur in community groups with religious backgrounds, can be resolved properly. Nasir, Secretary of the Forum for Religious Harmony of the Karanganyar Regency, related that in 2020, there was a conflict due to a misunderstanding about the establishment of houses of worship in the regency. He performed Tabayyun to the two groups so that they finally found the real root of the problem. The result was that the two groups were reconciled. ${ }^{17}$ Similarly, Rusdiyanto, secretary of the Forum for Religious Harmony of the Karanganyar regency, related that in 2020 in one of the cities in Karanganyar regency, there was a misunderstanding of the teachings of one religious group, causing polemics that led to tensions between groups. He performed tabayyun to them and finally got clarification. As a result, the two groups were reconciled. ${ }^{18}$

Based on interviews and some of the above studies it appears that the practice of tabayyun has provided solutions to various social conflicts. But to what extent can tabayyun practice be a resolution of social conflict in Indonesian society? This study seeks to find such significance. The problem of research is the extent to which the practice of tabayyun resolution in Indonesian society? The goal is that once the significance is

14 Ahmad Atabik, 'The Role of Indonesian Women for Conflict Resolution on Qur ' Anic Interpretation', Palastren: Jurnal Studi Gender IAIN Kudus, 12.2 (2019), 543-68.

${ }^{15}$ Uswatun Hasanah, 'Manajemen Konflik dalam Meningkatkan Kualitas Kerja Pada Lembaga Pendidikan Islam', Al-Idarah : Jurnal Kependidikan Islam, 10.1 (2020), 111

<http://103.88.229.8/index.php/idaroh/article/viewFile/ $6448 / 3603>$. found, Indonesian citizens will be more encouraged to practice tabayyun as a conflict resolution strategy. This research uses a qualitative approach using the library method and is also supported by data from interviews with Muslim figures in Karanganyar regency, Central Java, who have practiced tabayyun in resolving conflicts in society. These figures include: First, K.H. Khuzaini. He is a ulama who serves as chairman of the Forum for Religious Harmony (FKUB) of Karanganyar Regency. Second, Rusdiyanto. He is a Muslim scholar who serves as Secretary 1 FKUB of Karanganyar Regency. Third, Nasir. He is a Muslim scholar who served as Secretary 2 FKUB Karanganyar Regency. Fourth, Agus Sutikto. He is a Muslim scholar who is a member of FKUB Karanganyar Regency. Fifth, K.H. Hafidi. He is a scholar (ulama) and also the Caretaker of Pondok Pesentren Darul Amal, Jatioso, Karanganyar, Central Java. The sixth is K.H. Lipo. He is a ulama and Caretaker of Pondok Pesentren Al-Ikhsan, Jebres, Surakarta.

\section{The Plurality of Indonesia: An Opportunity and Challenge}

Indonesia is an island nation with a large population and has a diversity of tribes, customs, religions, and beliefs. When reviewed in more detail, Indonesia has two types of diversity, namely vertical and horizontal diversity ${ }^{19}$. This vertical diversity is drawn from the structure of society that has different layers and social levels between the upper and lower layers which include differences in social, economic, educational, and political levels, while horizontal diversity is drawn from the existence of social unity based on differences in ethnicity, religion, customs and

16 Citra Indraswari and Ari Prasetyo, 'Conflict Management of Business Activities in Islamic Perspective: Studied on Puspa Agro Central Market in East Java', Educational Research International, 6.2 (2017), 177-86.

17 Nasir, (Tabayyun significance in conflict resolution) Interview, \{ Tuesday, 26 Oktober 2021$\}$

${ }^{18}$ Rusdiyanto, (Tabayyun significance in conflict resolution) Interview, \{ Tuesday, 26 Oktober 2021\}

${ }^{19}$ Supriatin and Nasution. 
regional ${ }^{20}$. Plurality is therefore an inevitability that cannot be denied by the children of this nation.

The plurality can be an advantage as well as a challenge for the Indonesian nation. As expressed by Soetopo quoting Solasmono that although diversity in Indonesia can be an asset of nation-building, to take care of it is not easy, because it requires an open and sincere attitude to accept each other's differences, otherwise it will potentially cause social conflict between them ${ }^{21}$.

What are the opportunities for Indonesian plurality? First, the plurality of Indonesia is God's grace that can improve the quality of life ${ }^{22}$. This is in line with Zhang's assertion that "cultural diversity can enrich human life and development"23. Through this diversity, people can share cultural experiences and learn to openly understand their own culture and others. This experience will improve the quality of human life collectively and personally. Linton argues that "someone who knows nothing about other people's culture will not be able to truly understand his own culture" 24 . That is, openness to the culture of others is a way to understands one's own culture. Therefore, the plurality of Indonesia is a mercy for this nation.

Second, according to Lestari citing Hafner's view, Indonesian plurality can be a "classic locus" (best place/reference) for the concept of compound society ${ }^{25}$. This means that Indonesia with all its diversity can be one of the models for other nations in managing diversity. This privilege is what makes Indonesia the best learning place in realizing a multicultural society. No wonder that many countries are starting to be interested in learning about social harmony in Indonesia's experience. The founders of this nation tried to express this experience by the national slogan, Bhinneka Tunggal Ika ("unity in diversity"). In the motto, there is a wise admonition to unite without blaming diversity because in diversity is found the value of unity that unites all differences 26.

Third, the plurality of Indonesia becomes its attraction for domestic and foreign tourists. The diversity of cultures, customs, religions, and beliefs makes the country a unique and interesting place to visit ${ }^{27}$. This can be one source of state revenue. Prabhawati said that cultural richness and diversity has enormous potential for the advancement of the tourism industry in Indonesia, which will also have an impact on increasing the country's revenue ${ }^{28}$. These opportunities should encourage the government, stakeholders, and tourism sector players in improving the quality of the industry.

In addition to some of the above opportunities, the plurality of Indonesia is also a challenge and a threat to the nation ${ }^{29}$. First, diversity can sometimes be the "gateway" to various issues and potential conflicts that lead to divisions $^{30}$. Various issues of ethnic, religious, racial, and class background are easily used as propaganda tools in various social conflicts. This is evident from several social conflict events that have occurred in this nation, such as the riots in Situbondo in 1996, the May 1998 riots, the

\footnotetext{
${ }^{20}$ Pettalongi.

21 Sulasmono Bambang S., Keadilan Dalam Kemajemukan (Jakarta: Pustaka Sinar Harapan, 1998), p. 108.

22 Gina Lestari, 'Bhinnekha Tunggal Ika: Khasanah Multikultural Indonesia di Tengah Kehidupan Sara', Jurnal Pendidikan Pancasila dan Kewarganegaraan, 28.1 (2015), 31-37.

23 Junhao Zhang, 'Educational Diversity and Ethnic Cultural Heritage in the Process of Globalization', International Journal of Anthropology and Ethnology, 3.1 (2019), 1-10 (p. 2) <https://doi.org/10.1186/s41257-019-0022$\mathrm{x}>$.

24 Ralph Linton, In The Cultural Background of Personality, ed. by Yu Minmei and Chen Xuechang, 2007.
}

\author{
${ }^{25}$ Lestari. \\ ${ }^{26}$ Lestari. \\ ${ }^{27}$ Lestari. \\ 28 Adhiningasih Prabhawati, 'Upaya Indonesia
} dalam Meningkatkan Kualitas Pariwisata Budaya Melalui Diplomasi Kebudayaan', Journal of Tourism and Creativity, 2.2 (2018), 158-77.

29 Holifatul Hasanah and Sony Sukmawan, 'Berbingkai Kemajemukan Budaya, Bersukma Desakalapatra: Selidik Etnografi Atas Tradisi Tengger', Diglosia: Jurnal Kajian Bahasa, Sastra, dan Pengajarannya, 4.1 (2021), 79-90

<https://doi.org/10.30872/diglosia.v4i1.102>. ${ }^{30}$ Lestari. 
Ambon Riots in 1999, the Sampit tragedy in 2001, the Ambon Riots in 2011, and other events. In these events, it is not uncommon for ethnic, religious, racial, and class issues to be used as propaganda tools ${ }^{31}$.

Second, the plurality of Indonesia sometimes brings about intolerance. Hasanah and Sukmawan argue that the presence of diversity unaccompanied by a correct multicultural understanding will trigger disrespect, envy, hatred, strife can even lead to social conflict due to the emergence of intolerance among the community $^{32}$. This is evidenced by the many social conflicts over the past 14 years in Indonesia. Quoted from Kompas.scom, Hasanah, and Sukmawan presented social conflict data based on diversity as follows: "Diversity conflict reached 2,389 cases with a breakdown of $65 \%$ of religious background, and $20 \%$ of ethnic background, the rest was triggered by gender and sexual violence" ${ }^{\prime 33}$. All these events are triggered by the emergence of intolerance over the plurality of Indonesians.

\section{Social Conflict as a Social Phenomenon}

Etymologically conflict means strife, contention, the contention of opinions or desires $^{34}$. Conflict can also be meaningful as open conflicts occur in individuals or groups in a society or nation ${ }^{35}$. It usually does not happen spontaneously but there are many root factors causing $\mathrm{it}^{36}$. Jamaludin has argued that some of the root causes of conflict include the struggle for sources of ownership, social status, and uneven

31 R. Cecep Romli, 'Menguatkan Pancasila, Menata Kemajemukan Bangsa', Harmoni, 16.1 (2017), 184-94 <https://doi.org/10.32488/harmoni.v16i1.69>.

${ }^{32}$ Hasanah and Sukmawan.

${ }^{33}$ Hasanah and Sukmawan.

${ }^{34}$ Septiyan Hudan Fuadi, 'Resolusi Konflik Sosial Perspektif Hukum Islam dan Hukum Adat pada Pemilihan Kepala Desa Bajang Mlarak Ponorogo', Al-Manhaj: Jurnal Hukum dan Pranata Sosial Islam, 2.1 (2020), 86-110.

${ }^{35}$ M. Wahid Nur Tualeka, 'Teori Konflik Sosiologi Klasik dan Modern', Al-Hikmah, 3.1 (2017), 32-48 $<$ http://journal.um-

surabaya.ac.id/index.php/Ah/article/view/409>. ${ }^{36}$ Fuadi. power in society ${ }^{37}$. Diversity of interests in meeting physical, psychological, and social needs can also be a contributing factor to the onset of conflict $^{38}$. Furthermore, differences in the innate characteristics of individuals in an interaction such as physical characteristics, cleverness, knowledge, customs, beliefs, and so on can also be a trigger for conflict in society ${ }^{39}$

Nevertheless, human beings cannot escape from conflict. It is difficult to eliminate because it has become part of human life and is endemic to social relations ${ }^{40}$. So, what is social conflict? Social conflict is one form of social phenomenon that occurs in society ${ }^{41}$. Social conflict is a conflict between members of a society. What is social conflict? It is one form of social phenomenon that occurs in society ${ }^{42}$. In addition, social conflict can also imply social interaction between several parties in a society characterized by an attitude of intimidation, terrorizing, suppressing, and wanting to destroy each other. In social relations, social conflict is an inevitability, but this must be handled properly so as not to adversely affect the community. Community leaders must therefore understand the various forms of social conflict.

According to Soekanto there are five forms of social conflict ${ }^{43}$ : First, personal conflict. This conflict occurs when two or more individuals are involved in conflicts due to differences and so on. Second, racial conflict, which is a conflict arising from racial differences. Third, conflicts between social classes namely conflict caused by differences in interests between social classes.

37 Adon Nasrullah Jamaludin, Agama dan Konflik Sosial (Bandung: CV. Pustaka Setia, 2015), p. 40.

38 Fuadi.

${ }^{39}$ St. Aisyah, 'Konflik Sosial dalam Hubunga antar Umat Beragama', Jurnal Dakwah Tabligh, 15.2 (2014), 189_ 208

<https://doi.org/https://doi.org/10.24252/jdt.v15i2.348 $>$.

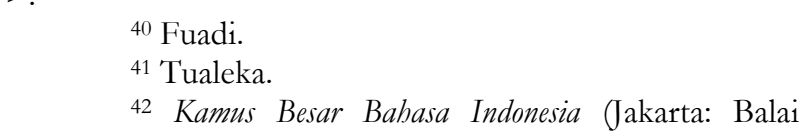
Pustaka, 2005), p. 587.

43 Soekanto Soerjono, Sosiologi Suatu Pengantar (Jakarta: Rajawali Pers, 1992), p. 86. 
Fourth, political conflict. This conflict occurs because of a conflict of interest or the political purpose of a person or group. Fifth, international conflicts. This conflict is caused by differences in interests that then affect the sovereignty of the country. The five forms of social conflict need to be resolved by finding the cause of the conflict to restore harmony in the community. This step is often referred to as conflict resolution. Conflict resolution is to deal with the causes of conflict and try to build new relationships between hostile groups $^{44}$. Furthermore, Suhardono defines conflict resolution as "an individual's way of solving a problem that is being faced with another individual voluntarily"45. In this conflict resolution, problem-solving prioritizes more democratic and constructive ways and an open attitude between the warring parties, so that they can solve their problems or through third parties $^{46}$. Clarity of the causes of conflict, openness, and honesty among the conflict are the main keys to peace.

\section{Conflict Resolution Efforts in the Community}

Conflict is a reality in social interaction that is unavoidable, so it needs to be managed properly so as not to cause further problems in society. One form of management is to seek conflict resolution. To be able to manage conflict resolution well, the main prerequisites that must be met by every component of the society are a forward-looking leadership and a strong desire to immediately end the conflict ${ }^{47}$. Indicators of a strong desire from all components of society to end the conflict appear as follows ${ }^{48}$. First, the desire to forgive each other. This is important in conflict resolution because opening the door to each other will make the problem not protracted. Second, a willingness to understand each other. This understanding is built on openness and

44 Tualeka.

45 Wisnu Suhardono, 'Konflik dan Resolusi', Salam: Jurnal Sosial dan Budaya Syar-I, 2.1 (2015), 1-16 <https://doi.org/10.15408/sjsbs.v2i1.2236>.

46 Suhardono. honesty over the root causes of conflict. The carious parties involved must begin to understand each other. Third, the willingness to help each other. If this desire begins to appear in a society under conflict, then a game is being created. Fourth, a desire to respect each other's rights. When each side respects the other's rights, this is a sign that they have understood their respective positions in society; the desire to end the conflict becomes greater. Fifth, accepting each other's differences and fulfilling their social obligations.

There are several stages in social conflict resolution. Afandi introduces the stages of conflict resolution in pesantren (boarding school) communities as follows ${ }^{49}$. First, silabturami or meeting the other party. This stage is a conflict prevention process because sometimes conflicts are caused by misunderstandings. Through silabturahmi, there is an open relationship and the early seeds of contention can be easily found. As a preventive stage, silahturabmi is a form of communication that contains elements of communication of two or more parties. With silabturahmi, the conflicting parties are taught that life grows out of an attitude of tolerance. Second, babsul masa'il or discussion over the problem at hand. At this stage, problem-solving is done through dialogue. Conflict is defined into a narrower scope so as not to widen and have a worse impact. Third, tabayyun. This stage emphasizes the clarification of an issue at hand. Tabayyun aims at clarification, rather than exploitation of the problem. Fourth, islah or reconciliation. In Arabic, the word means to be kind to each other. Here, the warring parties are committed to reconciliation. The elements that must exist in the islah stage are the willingness for reconciliation, the conflicting parties being present in a forum, holding a joint declaration for
${ }^{47}$ Heru Cahyono, 'Negara dan Masyarakat dalam Resolusi Konflik di Indonesia', Jurnal Penilitian Politik, 4.1 (2006), 72-73.

${ }^{48}$ Cahyono.

49 A. Afandi, 'Masyarakat Pesantren dan Resolusi Konflik', Jurnal Politik Universitas Nasional, 12.1 (2016), 1816-18. 
a settlement, upholding the peace treaty agreement, and the presence of mediators who monitor the course of peace agreements. Several stages of conflict resolution in the pesantren community can be applied in solving various problems that arise in the community, especially social conflicts of ethnic, religious, racial, and class backgrounds.

\section{Religion in Multicultural Societies}

When viewed from the point of view of sociology, religion can be defined as a view of life that must be applied in human life individually or as a group ${ }^{50}$. This is because religion has a role in personal and communal life. Personally, religion can provide a sense of calm, a sense of happiness, a sense of protection, a sense of success, and a sense of satisfaction with life experienced ${ }^{51}$. While communally religion provides justification and adherence to the norms of social life, so that it will stimulate the obedience of every member of society to the prevailing norms ${ }^{52}$. This proves that religion has a fairly important role in society.

Furthermore, what is the role of religion in a multicultural society? A multicultural society is a society that has a diversity of social groups with different cultural backgrounds but can coexist despite these differences ${ }^{53}$. However, this does not mean that there is zero conflict because conflict is endemic to social interaction ${ }^{54}$. Therefore, conflicts need to be properly and properly managed so as not to cause greater social impact $^{55}$. Again it is not diversity that matters but how we view and manage diversity ${ }^{56}$. This is where religion should be present: to participate in the management of diversity so as to avoid

50 Ali Amran, 'Peranan Agama dalam Perubahan Sosial Masyarakat', Hikmah, 1. 2 (2015), 23-39.

51 Ahmad Taufik, 'Agama dalam Kehidupan Individu’, Agama, 1.1 (2019), 67.

52 Amran.

53 Ketut Gunawan and Yohanes Rante, 'Manajemen Konflik Atasi Dampak Masyarakat Multikultural di Indonesia', Jurnal Mitra Ekonomi dan Manajemen Bisnis, 2.2 (2001), 212-24.

54 Suhardono.

55 Gunawan and Rante. triggering social conflict in society. Religion through its social solidarity element can be a social adhesive for the compound society ${ }^{57}$. In this element, religion can play a role in bridging tensions and maintaining the continuity of society when faced with various challenges of life ${ }^{58}$. In addition, through the values inherent in it, religion can polish each individual to behave obediently to religious and social norms, apply love, peace, and respect for others in diversity ${ }^{59}$. Religion can also encourage its adherents to have an open, honest attitude and uphold the truth without sacrificing humanity. From this explanation, it appears that religion plays an important the role in creating harmony in a multicultural society.

\section{The Practice of Tabayyun in Islamic Theology}

In general, tabayyun means to render something that was previously unclear into something that is well-understood by the concerned parties ${ }^{60}$. Furthermore, the use of the word in the context of the Qur'an has the meaning of an action of investigating the validity of claim or question ${ }^{61}$. One example of this practice is seen in surah An Nisa verse 94 which is explained by Imam Ahmad Musthafa in the interpretation of Al-Maraghi as follows: "This verse is an order to the Muslims who commit jihad in the way of Allah so as not to rush in attacking their opponents until it is truly verified that they are infidels and worthy of war, even Allah forbids killing a person who professes to believe only because the Muslims doubt the confession" ${ }^{\prime 2}$. According to Mildad based on the Interpretation of the Qur'an of the Ministry of Religion, 2004, explains the use of the word

56 Rizal Mubit, 'Peran Agama dalam Multikulturalisme Masyarakat Indonesia', Epistemé: Jurnal Pengembangan Ilmu Keislaman, 11.1 (2016), 163-84 <https://doi.org/10.21274/epis.2016.11.1.163-184>.

${ }^{57}$ Mubit.

58 Mubit.

${ }^{59}$ Mubit.

${ }^{60}$ Azzuhri.

${ }^{61}$ Azzuhri.

${ }^{62}$ Ahmad Musthafa al-maraghi, Tafsir Al-Maraghi (Semarang: Thoha Putra, 2003). 
tabayyun in this verse as follows: "the word tabayyun is an imperative verb in the plural, from the verb tabayyana. The verbal noun is at-tabayyun, which means to seek clarity of the nature or truth of a fact carefully" ${ }^{\prime 3}$.

Another example related to the practice of tabayyun in the time of Rasulallah SAW is the case of al-Walid Ibn 'Ugbah Ibn Abi Muith, who was sent by the Prophet SAW to collect the alms-tax to to al-Musthalag tribe ${ }^{64}$. At that time the people heard the prophet's messenger coming and they came out of his village and brought their alms, but it was considered by al-Walid as an attack. Therefore, the news was conveyed to Rasulallah SAW that the al-Musthalag tribe had refused to pay the alms-tax and had intended to attack. Then Rasulallah SAW ordered al-Walid to investigate the matter thoroughly and prohibited him to attack the tribe before the problem was clear. Finally, he told his informant to investigate the situation in the village, and it was clarified that the village heard the call to prayer and the community also performed congregational prayers. Then alWalid visited them and received the alms-tax that had been collected. This event is the occasion for the revelation of the verses of the Qur'an in surah al-Hujurat 49 verse 6 which reads as follows:

"O you who have believed, if there comes to you a disobedient one with information, investigate, lest you harm a people out of ignorance and become, over what you have done, regretful"'65.

Through this story, it can be concluded that Tabayyun is very important to prevent disasters from happening to people ${ }^{66}$. The practice of tabayyun is part of the praxis of Islamic theology that teaches people to always be careful and seek clarity on a problem to avoid mistakes and disharmony in association ${ }^{67}$. In addition, this practice can ward off misunderstandings, suspicions, regrets, and even accusations against others for lying ${ }^{68}$. The practice of tabayyun can encourage openness and honesty in solving every problem in living together. This can be seen from the stages of tabayyun as follows ${ }^{69}$. First, the presence of the conflicting parties. Second, the presence of the mediator accepted by each conflicting party. Third, each conflicting party explaining the issue. Fourth, the mediator offering a solution. Fifth, mutual agreement between parties.

Based on interviews conducted by the researchers, it was found that tabayyun is the process of clarifying news or problem from the original source, which aims at arriving at a solution. The researcher's conclusions are derived from the following interview results:

Table 1. Interview results on the meaning of tabayyun $^{70}$

\begin{tabular}{|c|c|c|}
\hline Respond & Position & $\begin{array}{c}\text { Meaning of } \\
\text { Tabbayun }\end{array}$ \\
\hline $\begin{array}{l}\text { K.H } \\
\text { Khuzaini }\end{array}$ & $\begin{array}{l}\text { Chairman of } \\
\text { FKUB } \\
\text { Karanganyar } \\
\text { Regency }\end{array}$ & $\begin{array}{l}\text { Clarification of the } \\
\text { problem through } \\
\text { the original source }\end{array}$ \\
\hline Rusdiyanto & $\begin{array}{l}\text { Secretary } 1 \\
\text { FKUB } \\
\text { Karanganyar } \\
\text { Regency }\end{array}$ & $\begin{array}{l}\text { Clarification of } \\
\text { sources of } \\
\text { information to the } \\
\text { main source }\end{array}$ \\
\hline Nasir & $\begin{array}{l}\text { Secretary } 2 \\
\text { FKUB } \\
\text { Karanganyar } \\
\text { Regency }\end{array}$ & $\begin{array}{l}\text { Clarification of the } \\
\text { information } \\
\text { obtained before } \\
\text { making a decision }\end{array}$ \\
\hline
\end{tabular}

63 Jamal Mildad, 'KOMUNIKASI MASSA DALAM PERSPEKTIF ISLAM (Kajian Terhadap Alquran Pada Ayat-Ayat Tabayyun)', SOURCE: Jurnal Ilmu Komunikasi, 2.2 (2018), $\quad 1-6 \quad$ (p. 3) <https://doi.org/10.35308/source.v2i2.300>.

${ }^{64}$ Iffah Al Walidah, 'Tabayyun Di Era Generasi Millenial', Jurnal Living Hadis, 2.2 (2018), 317 (p. 324) <https://doi.org/10.14421/livinghadis.2017.1359>.

${ }^{65}$ D. A. Agama, Al-Qur'an Terjemahan (Semarang: Cv Toha Putra, 1989).

${ }^{66}$ Walidah, p. 324.
${ }^{67}$ Hasanah, pp. 6-7.

${ }^{68}$ Khaerul Umam, 'Mereda Konflik; Menghargai Identitas (Studi Kasus Pada Aliran-Aliran Kepercayaan Yang Ada Di Indramayu)', Asketik, 2.2 (2018), 163-74 (p. 163) < https://doi.org/10.30762/ask.v2i2.911>.

${ }^{69}$ Afandi, p. 1817.

${ }^{70}$ Khuzaini, Rusdiyanto, Nasir, Sutikto , Lipo (Meaning of Tabbayun), Interview, \{Tuesday, 26 Oktober $2021\}$ 


\begin{tabular}{lll}
\hline Agus Sutikto & $\begin{array}{l}\text { Members of } \\
\text { FKUB } \\
\text { Karanganyar } \\
\text { Regency }\end{array}$ & $\begin{array}{l}\text { Clarifying the } \\
\text { parties in conflict } \\
\text { to seek clarity on } \\
\text { the issue }\end{array}$ \\
\hline K.H Hafidi & $\begin{array}{l}\text { Caretaker of } \\
\text { Pondok } \\
\text { Pesentren Darul } \\
\text { Amal, Jatioso, } \\
\text { Karanganyar }\end{array}$ & $\begin{array}{l}\text { Clarifyingthe news } \\
\text { so that there is no } \\
\text { slander }\end{array}$ \\
\hline K.H Lipo & $\begin{array}{l}\text { Caretaker of } \\
\text { Pondok } \\
\text { Pesentren Al- } \\
\text { Ikhsan, Jebres, } \\
\text { Surakarta }\end{array}$ & $\begin{array}{l}\text { Clarifying the } \\
\text { problem to make } \\
\text { clear a solution }\end{array}$ \\
& & \\
\hline
\end{tabular}

\section{The Significance of the Practice of Tabayyun as Conflict Resolution in Society}

Indonesia is a country that has the largest number of Muslims in the world, so surely tabayyun practice is very familiar and can be one of the methods in resolving conflicts that arise in society. For example, on Tuesday, August 20, 2019, the Indonesian Ulema Council (MUI) invited Ustaz Abdul Somad to talk about his video which seems to insult the beliefs of one particular religion ${ }^{71}$. Once the person has clarified the content of the video, the issue can finally be handled properly so as not to cause ongoing social conflicts. To what extent is the significance of the practice of tabayyun as a conflict resolution strategy in this multicultural Indonesian society?

First, Syarifudin explained that the practice of tabayyun can improve the quality of information submitted and received ${ }^{72}$. Because through Tabayyun the main source of information, messages, and recipients of messages can be clarified and verified ${ }^{73}$. The practice of tabayyun can avoid misunderstandings and disinformation. This became very important as hoax news emerged among the public. The number of hoax news in 2020 increased from 1,221 in 2019 to 2,024 in $2020^{74}$. This data is quite concerning because, with many emergences of hoax news containing elements of ethnicity, religion, race, and class, hostility and hatred can be easily incited and lead to social conflict ${ }^{75}$. According to Syarifudin, the practice of tabayyun will further clarify the quality of information and prevent mistakes in making decisions ${ }^{76}$. Tabayyun practices can produce good and correct quality information that aligns with the characteristics of quality information. Widarsono explained the characteristics of quality information as follows ${ }^{77}$ : First, it is relevant to reduce uncertainty. Second, it is reliable so that it is not biased, but rather accurate, and trustworthy. Third, complete means intact and does not leave important aspects behind an event. Fourth, it is on time. This means that information is always available when decision-making is being made. Fifth, plain, which means presented in a useful and understandable form. Sixth, it can be verified so that it can be tested by two or more people independently, and will produce the same information. Through tabayyun practice all disinformation will be clarified to produce good and correct quality information so that there is no misunderstanding, suspicion, and even potential social conflict in a diverse society like Indonesia.

Second, the practice of tabayyun can clarify the root cause of a conflict ${ }^{78}$. Sometimes a conflict starts from a problem that is not yet clear, such that when it is left unclarified it would lead to social conflict. To prevent this, it takes thoroughness and clarification of the root cause

behind $i^{79}$. For the pesantren community,
${ }^{71}$ Intan Umbari Prihatin, 'MUI Hari Ini Undang
Ustaz Abdul Somad Untuk
Https:/ / Www.Merdeka.Com/, 2019.
72 Faisal Syarifudin, 'Urgensi Tabayyun dan Kualitas Informasi dalam Membangun Komunikasi', AlKuttab : Jurnal Kajian Perpustakaan, Informasi dan Kearsipan, 1.2 (2019), 29-39 <https://doi.org/10.24952/ktb.v1i2.1994>.

${ }^{73}$ Syarifudin.

${ }^{74}$ Wahyunanda Kusuma Pertiwi, 'Jumlah Hoaks di Indonesia Meningkat, Terbanyak Facebook', Kompas.Com, 2020.
Rahayu Kurniawati, 'Pertanggungjawaban Pidana Atas Penyebaran Berita Bohong (Hoax) di Media Sosial', Dinamika, Jurnal Ilmiah Ilmu Hukum, 26.4 (2020), 431.

76 Syarifudin.

77 Agus Widarsono, 'Pengaruh Kualitas Informasi Manajemen terhadap Kinerja Manajerial (Survey pada Perusahaan Go-Publik di Jawa Barat)', Jurnal Akuntansi FE Unsil, 2.2 (2007), 286-99.

${ }^{78}$ Fuadi.

${ }^{79}$ Fuadi. 
tabayyun has become one of the familiar steps in conflict resolution, because it has succeeded in becoming one of the methods that can clarify a problem ${ }^{80}$. Through tabayyun, pesantren people are taught not to exploit conflicts, but to try to clarify the root of the problem and be resolved properly ${ }^{81}$. According to Afandi, based on this, the senior scholar tend not to prolong the problem but still admit that there is a mistake in each person ${ }^{82}$. This practice if applied in Indonesian society of diverse tribes, religions, races, and groups will encourage harmony in differences. If there are issues of ethnic, religious, racial, and class background, then the conflicting parties can immediately flock to find the real root of the problem. Is it triggered by differences or just an issue that is used as a trigger for disputes between the children of the nation? Tabayyun can be a discussion space to clear up problems and jointly find the best solution.

Third, tabayyun practice can prevent social conflict due to unclear root problems. Tabayyun's significance is shown in surah al-Hujurat 49 verse 6 , that believers should seek clarity of the news they receive so that they do not inflict calamity upon anyone. Tabayyun can prevent each side from misunderstanding, hostility even to bloodshed $^{83}$. In a plural society, conflict is a form distrust, but if friction begins to occur this is due to differences. The practice of tabayyun can be the first stage in conflict resolution to prevent worse situations ${ }^{84}$.

Fourth, the practice of tabayyun can foster social ethics based on religious values in Islamic theology. Indonesia as the country with the largest Muslims in the world. It can contribute to the world on social ethics through tabayyun practice. This is especially true in multicultural societies. The potential for social conflict due to differences in ethnicity, religion, race, and class is very large.
Through the practice of tabayyun, every member of the community is invited to communicate these differences so as not to cause potential social conflicts. Fuadi said that "Islam teaches people to deal with every problem wisely and put social ethics first" ${ }^{\text {8 }}$.

Some respondents in the interview also stated that the practice of tabayyun provides significant value as conflict resolution in compound societies. Even the practice of tabayyun can be a place of silahturahmi between the nation's children. This conclusion can be seen from the following table:

Table 2. Interview results on the significance of tabayyun in compound society ${ }^{86}$

\begin{tabular}{|c|c|c|}
\hline Respond & Position & $\begin{array}{l}\text { Significance of } \\
\text { Tabayyun }\end{array}$ \\
\hline $\begin{array}{l}\text { K.H } \\
\text { Khuzaini }\end{array}$ & $\begin{array}{l}\text { Chairman of } \\
\text { FKUB } \\
\text { Karanganyar } \\
\text { Regency }\end{array}$ & $\begin{array}{l}\text { Minimize } \\
\text { misunderstandings } \\
\text { between the } \\
\text { nation's children }\end{array}$ \\
\hline Rusdiyanto & $\begin{array}{l}\text { Secretary } 1 \\
\text { FKUB } \\
\text { Karanganyar } \\
\text { Regency }\end{array}$ & $\begin{array}{l}\text { Reduce vagueness } \\
\text { and multi- } \\
\text { interpretation of an } \\
\text { issue that arises in } \\
\text { a pluralistic society }\end{array}$ \\
\hline Nasir & $\begin{array}{l}\text { Secretary } 2 \\
\text { FKUB } \\
\text { Karanganyar } \\
\text { Regency } \\
\end{array}$ & $\begin{array}{l}\text { It is form of } \\
\text { silahturami between } \\
\text { community groups }\end{array}$ \\
\hline Agus Sutikto & $\begin{array}{l}\text { Members of } \\
\text { FKUB } \\
\text { Karanganyar } \\
\text { Regency }\end{array}$ & $\begin{array}{l}\text { Strengthen } \\
\text { relationships in the } \\
\text { family and } \\
\text { strengthen } \\
\text { togetherness as a } \\
\text { nation's children }\end{array}$ \\
\hline K.H Hafidi & $\begin{array}{l}\text { Caretaker of } \\
\text { Pondok } \\
\text { Pesentren Darul } \\
\text { Amal, Jatioso, } \\
\text { Karanganyar } \\
\end{array}$ & $\begin{array}{l}\text { Connect } \\
\text { relationships and } \\
\text { create peace in } \\
\text { society. }\end{array}$ \\
\hline K.H Lipo & $\begin{array}{l}\text { Caretaker of } \\
\text { Pondok } \\
\text { Pesentren Al- } \\
\text { Ikhsan, Jebres, } \\
\text { Surakarta } \\
\end{array}$ & $\begin{array}{l}\text { Being the door of } \\
\text { silabturami between } \\
\text { the children of the } \\
\text { nation }\end{array}$ \\
\hline
\end{tabular}

85 Fuadi.

${ }^{86}$ Khuzaini, Rusdiyanto, Nasir, Sutikto, Lipo, (The Significance of Tabayyun in Compound Society) Interview, \{Tuesday, 26 Oktober 2021\} 


\section{Conclusion}

Indonesia is a multicultural country with a variety of tribes, religions, races, and groups. Such diversity can potentially lead to social conflicts, but if handled appropriately it can be an opportunity for the progress of nation-building. Through tabayyun's very familiar practice in Islamic theology, conflict resolution can be built. By exploring the root causes of conflict carefully and clarifying them honestly and openly, each party will be able to address the problem proportionally. The practice of tabayyun has great significance as a conflict resolution strategy in multicultural Indonesian society because it can improve the quality of information being conveyed and received, clarify the root of problems in a conflict, prevent disasters due to vagueness of the root of the problem in the conflict, and foster social ethics based on religious values in Islamic theology.

\section{References}

\section{Books}

Adon Nasrullah Jamaludin, Agama dan Konflik Sosial. Bandung: CV. Pustaka Setia, 2015.

Agama, D. A., Al-Qur'an Terjemahan . Semarang: Cv Toha Putra, 1989

Ahmad Musthafa al-maraghi, Tafsir Al-Maraghi (Semarang: Thoha Putra, 2003)

Bambang S., Sulasmono, Keadilan Dalam Kemajemukan (Jakarta: Pustaka Sinar Harapan, 1998)

Tim, Kamus Besar Bahasa Indonesia. Jakarta: Balai Pustaka, 2005.

Panggabean, S. Rizal, Pola-Pola Konflik Keagamaan di Indonesia (1990-2008). Jakarta: Asia Foundation, 2009.

Soerjono, Soekanto, Sosiologi Suatu Pengantar. Jakarta: Rajawali Pers, 1992.

Rafsanjani, Brian, 'Sikap Tabayyun dalam AlQur'an Menurut Mufassir dan Kontekstualisasi Pada Problematika Pemberitaan Media Sosial' (UIN Sunan Ampel, 2018)

\section{Journals}

Afandi, A., 'Masyarakat Pesantren dan Resolusi Konflik', Jurnal Politik Universitas Nasional, 12.1 (2016), 125513

Agus Widarsono, 'Pengaruh Kualitas Informasi Manajemen terhadap Kinerja Manajerial (Survey Pada Perusahaan Go-Publik di Jawa Barat)', Jurnal Akuntansi FE Unsil, 2.2 (2007)

Ahmad Taufik, 'Agama dalam Kehidupan Individu’, Agama, 1.1 (2019), 67

St. Aisyah, 'Konflik Sosial dalam Hubungan antar Umat Beragama', Jurnal Dakwah Tabligh, 15.2 (2014), 189-208 $<$ https://doi.org/https://doi.org/10.24252 /jdt.v15i2.348>

Amran, Ali, 'Peranan Agama dalam Perubahan Sosial Masyarakat', Hikmah, II (2015), 23-39

Atabik, Ahmad, 'The Role of Indonesian Women for Conflict Resolution on Qur'anic Interpretation', Palastren: Jurnal Studi Gender IAIN Kudus, 12.2 (2019), 543-68

Azzuhri, Anggi, 'Tabayyun As a Crucial Aspect in the Quranic Concept of Ummah Analysis of "Tabayyun" in Sura Al-Hujuraat (49:6)', Hunafa: Jurnal Studia Islamika, 17.2 (2020), 145-65

$<$ https://doi.org/10.24239/jsi.v17i2.603.27 $-46>$

Cahyono, Heru, 'Negara dan Masyarakat dalam Resolusi Konflik di Indonesia', Jurnal Penilitian Politik, 4.1 (2006)

Fuadi, Septiyan Hudan, 'Resolusi Konflik Sosial Perspektif Hukum Islam dan Hukum Adat pada Pemilihan Kepala Desa Bajang Mlarak Ponorogo', Al-Manhaj: Jurnal Hukum dan Pranata Sosial Islam, 2.1 (2020), 86-110

Gunawan, Ketut, and Yohanes Rante, 'Manajemen Konflik Atasi Dampak Masyarakat Multikultural di Indonesia', Jurnal Mitra Ekonomi dan Manajemen Bisnis, 2.2 (2001), 212-24

Hasanah, Holifatul, and Sony Sukmawan, 'Berbingkai Kemajemukan Budaya, Bersukma Desa Kalapatra: Selidik Etnografi Atas Tradisi Tengger', Diglosia: Jurnal Kajian Bahasa, Sastra, dan Pengajarannya, 4.1 (2021), 79-90 
$<$ https://doi.org/10.30872/diglosia.v4i1.10 $2>$

Hasanah, Uswatun, 'Manajemen Konflik dalam Meningkatkan Kualitas Kerja pada Lembaga Pendidikan Islam', Al-Idarah: Jurnal Kependidikan Islam, 10.1 (2020), 1-11 $<$ http://103.88.229.8/index.php/idaroh/ar ticle/viewFile/6448/3603>

Indraswari, Citra, and Ari Prasetyo, 'Conflict Management of Business Activities In Islamic Perspective: Studied on Puspa Agro Central Market in East Java', Educational Research International, 6.2 (2017), 177-86

Jati, Wasisto Raharjo, 'Kearifan Lokal Sebagai Resolusi Konflik Keagamaan', Walisongo: Jumal Penelitian Sosial Keagamaan, 21.November (2013), 393-416

Lestari, Gina, 'Bhinnekha Tunggal Ika: Khasanah Multikultural Indonesia di Tengah Kehidupan Sara', Jurnal Pendidikan Pancasila Dan Kewarganegaraan, 28.1 (2015), 31-37

Lindawaty, Debora Sanur, 'Konflik Ambon: Kajian Terhadap Beberapa Akar Permasalahan dan Solusinya', Politica, 2.2 (2011), 271-97

Linton, Ralph, In The Cultural Background of Personality, ed. by Yu Minmei and Chen Xuechang, 2007

Mildad, Jamal, 'Komunikasi Massa dalam Perspektif Islam (Kajian Terhadap Alquran Pada Ayat-Ayat Tabayyun)', Source: Jurnal Ilmu Komunikasi, 2.2 (2018), 1-6 $<$ https://doi.org/10.35308/source.v2i2.30 $0>$

Mubit, Rizal, 'Peran Agama dalam Multikulturalisme Masyarakat Indonesia', Epistemé: Jurnal Pengembangan Ilmu Keislaman, $11.1 \quad$ (2016), 163-84 $<$ https://doi.org/10.21274/epis.2016.11.1. 163-184>

Pertiwi, Wahyunanda Kusuma, 'Jumlah Hoaks di Indonesia Meningkat, Terbanyak Facebook', Kompas.Com, 2020

Pettalongi, Sagaf S, 'Islam dan Pendidikan Humanis dalam Resolusi Konflik Sosial', Cakrawala Pendidikan, 0.2 (2013), 172-82 <https://doi.org/10.21831/cp.v0i2.1474>
Prabhawati, Adhiningasih, 'Upaya Indonesia dalam Meningkatkan Kualitas Pariwisata Budaya Melalui Diplomasi Kebudayaan', Journal of Tourism and Creativity, 2.2 (2018), $158-77$

Rahayu Kurniawati, Yunita, 'Pertanggungjawaban Pidana Atas Penyebaran Berita Bohong (Hoax) di Media Sosial', Dinamika, Jurnal Ilmiah Ilmu Hukum, 26.4 (2020)

Romli, R. Cecep, 'Menguatkan Pancasila, Menata Kemajemukan Bangsa', Harmoni, 16.1 (2017), 184-94 $<$ https://doi.org/10.32488/harmoni.v16i1. 69>

Suhardono, Wisnu, 'Konflik dan Resolusi', Salam: Jurnal Sosial dan Budaya Syar-I, 2.1 (2015), 116

<https://doi.org/10.15408/sjsbs.v2i1.2236 $>$

Supriatin, Atin, and Aida Rahmi Nasution, 'Implementasi Pendidikan Multikultural dalam Praktik Pendidikan di Indonesia', Elementary: Jurnal Ilmiah Pendidikan Dasar, 3.1 (2017),

$<$ https://doi.org/10.32332/elementary.v3i $1.785>$

Syarifudin, Faisal, 'Urgensi Tabayyun dan Kualitas Informasi dalam Membangun Komunikasi', Al-Kuttab: Jurnal Kajian Perpustakaan, Informasi dan Kearsipan, 1.2 (2019), 29-39 <https://doi.org/10.24952/ktb.v1i2.1994>

Tualeka, M. Wahid Nur, 'Teori Konflik Sosiologi Klasik dan Modern', Al-Hikmah, 3.1 (2017), 32-48 <http://journal.umsurabaya.ac.id/index.php/Ah/article/view/ 409>

Umam, Khaerul, 'Mereda Konflik; Menghargai Identitas (Studi Kasus Pada Aliran-Aliran Kepercayaan Yang Ada di Indramayu)', Asketik, $\quad 2.2 \quad$ (2018), 163-74 <https://doi.org/10.30762/ask.v2i2.911>

Umbari Prihatin, Intan, 'MUI Hari Ini Undang Ustaz Abdul Somad Untuk Bertabayyun', Https://Www.Merdeka.Com/, 2019

Walidah, Iffah Al, 'Tabayyun di Era Generasi Millenial', Jurnal Living Hadis, 2.2 (2018), 317 
$<$ https://doi.org/10.14421/livinghadis.201 $7.1359>$

Zhang, Junhao, 'Educational Diversity and Ethnic Cultural Heritage in the Process of Globalization', International Journal of Anthropology and Ethnology, 3.1 (2019), 1-10 $<$ https://doi.org/10.1186/s41257-0190022-x>

\section{Interviews}

Nasir, (Tabayyun significance in conflict resolution) Interview, \{Tuesday, 26 October $2021\}$

Rusdiyanto, (Tabayyun significance in conflict resolution) Interview, \{Tuesday, 26 October $2021\}$

Khuzaini, Rusdiyanto, Nasir, Sutikto, Lipo (Meaning oftabbayun) Interview, \{Tuesday, 26 Oktober 2021\}

Khuzaini, Rsdiyanto, Nasir, Sutikto, Lipo (The Significanceof tabayyun in compound society) Interview, \{Tuesday, 26 October 2021 